\title{
The IMF Getting what it Needs in (as) the Aftermath of the Crisis
}

\author{
PABlo Moreno \\ Banco de España, C/ Alcalá, 48, 28014 Madrid, España. E-mail: pmoreno@bde.es
}

\begin{abstract}
Since 2009, the IMF has profoundly transformed all of its major policies in governance, surveillance, lending, and resources; leading to an institutional metamorphosis. This work looks at the fundamental changes in Fund's main policies focusing on two broad questions: (i) what has been done?, placing into context the magnitude and nature of the policy changes; and, specially, (ii) what more can be done?, following a positive approach on the additional reforms that can be pursued, taking into account the current context of reform fatigue and the state of the debate within the IMF.
\end{abstract}

Keywords: IMF, Governance, Institutional Culture, Quotas, Surveillance and Lending Policies, Resources.

\section{El FMI obteniendo lo que necesitaba tras (como consecuencia de) la crisis}

\section{RESUMEN}

Desde 2009, el FMI ha transformado profundamente todas sus principales políticas de gobernanza, vigilancia, préstamos y recursos; dando lugar a una metamorfosis institucional. Este trabajo analiza los cambios en las principales políticas del Fondo centrándose en dos grandes preguntas: (i) ¿Qué reformas se han llevado a cabo?, poniendo en contexto la magnitud y la naturaleza de las reformas acometidas; y, sobre todo, (ii) ¿qué más se puede hacer?, siguiendo un enfoque positivo sobre las reformas adicionales que pueden impulsarse, teniendo en cuenta el actual contexto de fatiga reformista y el estado del debate en el seno del FMI.

Palabras clave: FMI, gobernanza, cultura institucional, cuotas, políticas de vigilancia y préstamo, recursos.

JEL Classification: F53

\footnotetext{
${ }^{*}$ The analyses, opinions, and findings of this study represent the views of the author; they are not necessarily those of the Banco de España.
}

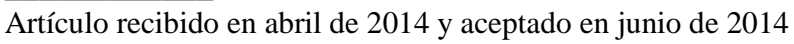

Artículo disponible en versión electrónica en la página www.revista-eea.net, ref. ə-32309 


\section{INTRODUCTION}

"You can't always get what you want/ But if you try sometimes, well you just might find/ You get what you need" (The Rolling Stones, 1968)

From the fall of 2008, the G20 has fostered a series of far-reaching initiatives in response to the global financial crisis, which have laid the foundations of a New International Economic Order (NIEO) based on three main elements: the configuration of the G20 as the forum for international economic coordination (replacing the G7), the strengthening of the institutional pillars of the Bretton Woods system -the International Monetary Fund (IMF or Fund), the World Bank, and the World Trade Organization (in this case to a lesser degree and more along the lines of avoiding a regression to protectionism)-, and the establishment of a new pillar of financial regulation and supervision, the Financial Stability Board (FSB).

The IMF has undergone a metamorphosis on its operations and functions that started early in 2009. It has transformed all of its major policies -governance and institutional culture, surveillance and lending policies, and its resources-. The challenges that the IMF has coped with are numerous, including the updating of its policies to increasingly integrated financial markets and world economy -through better surveillance and historically large programs-, the new role of emerging and developing countries (EMDCs) -which have become the engine of world growth since the late 90s, reaching around half of the world's GDP-, or working towards a new macroeconomic consensus in the post-crisis world.

After this reform process, the Fund has placed itself at the center of the international response to the crisis, turning around the debate on the Fund's irrelevance that was still alive well into 2008. This work looks at the fundamental changes in the Fund's main policies -(1) Governance, (2) Surveillance, (3) lending and resources- focusing on two broad questions: (i) what has been done?, placing into context the magnitude and the nature of the policy changes; and, specially, (ii) what more can be done?, following a positive approach on the additional reforms that can be pursued in a context where there is reform fatigue, largely because of the very significant advances already undertaken $^{1}$.

\footnotetext{
${ }^{1}$ Moreno (2013) largely looks at the first question of the reforms undertaken at the Fund. Drawing from it, this paper extends this analysis looking into more detail on the pending reforms that can be achieved. The focus is on the core Fund policies leaving aside its technical assistance and low-income country policies.
} 


\section{GOVERNANCE}

When looking at the governance of the IMF it is useful to consider a dual decision-making structure (see Figure 1): the formal structure (squares); and the informal one (circles). The first is represented by the Board and the Management and staff. Following principal-agent models, member countries (the principal) delegate in Management and the staff (the agent) the power of initiative and of carrying-out the policies, while maintaining control mechanisms and the ability to change the direction of the policies of the Fund through the Board ${ }^{2}$.

Figure 1

Governance structure of the IMF

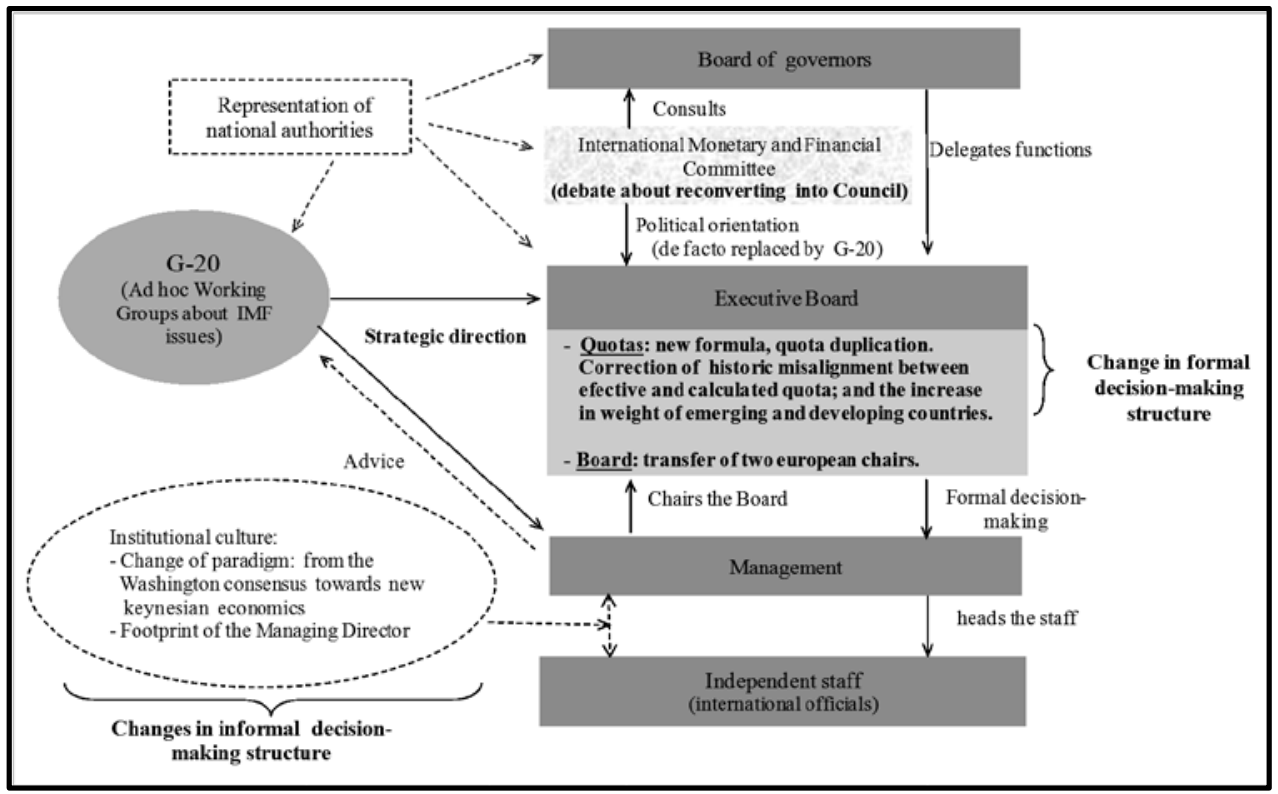

Source: Own elaboration based on Martinez-Diaz (2008) ${ }^{3}$.

The informal structure is a network of influence in decision making, including the political weight of countries or group of countries (the different Gs)- here, since 2009, the Fund's strategic direction has shifted from the G7 to the G20-, and the institutional culture, i.e. the ideological and academic background of staff and management, given their high capacity to orientate the policies of the IMF with their power of initiative. Since 2009, there have been many changes in both structures. Following, we concentrate on two areas of special

\footnotetext{
${ }^{2}$ The governance of the IMF is better approximated by theories of delegation and principal-agent models, rather than by realism or bureaucratic theories (see Momani, 2008).

${ }^{3}$ Published in Moreno (2012 and 2013).
} 
relevance that still have reforms pending ${ }^{4}$ : (1.1) the institutional culture, (1.2) the quota system [and the Executive Board].

\subsection{Institutional Culture}

\subsubsection{What has been done? The end of the Washington Consensus}

The so-called "Washington Consensus" ${ }^{5}$ labels the set of policies considered necessary for growth and generally applied by the Washington-based IMF and the World Bank. The recommendations are not always the same depending on the author, although the core policies that have focused academic analysis are: fiscal and monetary stabilization, liberalization of prices and interest rates, liberalization of trade and capital flows, and privatization. As noted by Boughton (2004), the Consensus dominated IMF policy in the 90s, both officially and in the institutional culture, albeit with important nuances depending on the specificities of each country. Further, on its report on the Fund's performance on the years prior to the global financial crisis, the IEO (2011) identifies a "group thinking" within the IMF guided by a general philosophy in favor of laissez faire and market discipline, including a general belief on the self-correcting capacity of financial markets and a policy of no bail-outs to avoid moral hazard problems.

Of course, already from late 2008, the policies applied broke this pre-crisis neo-classical consensus. Advanced economies applied expansionary macroeconomic policies, widespread bailouts of the financial systems, and a widening of the regulation and surveillance of the financial sector (to correct market failures), including new capital requirements under Basel III, and a new international institution for the coordination of regulation, the Financial Stability Board (FSB).

The Fund also participates both, outspokenly advocating for a new Keynesian expansionary approach -generally, supporting continued accommodative monetary policy and delaying the emphasis of the fiscal consolidation to the medium-term- ${ }^{6}$; and through its enlarged lending policy, which frontloads

\footnotetext{
${ }^{4}$ For a more detailed analysis on governance see Moreno (2013, chapter 4).

${ }^{5}$ Williamson first used the term in the Conference of the Institute for International Economics in Latin America in 1989, and published it a year later (Williamson 1990). He referred to policies to be applied in Latin America, but it has later evolved to identify the set of policies generally applied by the IMF and the World Bank to developing countries.

${ }^{6}$ These remain as the general recommendations in the Annual Meeting from 2009 through 2013 (see for instance IMF 2012b, 2013a). On fiscal policy, the recommendations have shifted from a general call to short-term expansionary policies in 2009; to advocating an immediate fiscal adjustment in some countries, especially in Europe after the 2010 sovereign debt crisis; to shortterm fiscal stimulus combined with an objective of medium-term fiscal consolidation for countries with margin (surplus countries and those supporting global demand such as the US) from 2011.
} 
loans, delays fiscal adjustment, and endorses bailing out policies in borrowing countries (IMF, 2012a). In April 2009, at the G20 summit in London, Gordon Brown staged the break with the neoclassical doctrine announcing at the press conference that "the old Washington consensus is over" (SkyNews, 2009).

\subsubsection{What more can be done? In search of a new consensus}

It is difficult to keep track of the numerous contributions to redefine macroeconomic policy, and even more so to try to identify where is the room for consensus, as policy makers are clearly differing on their strategies, with the US, the UK and Japan on the more expansionary and innovative side -specially on non-conventional monetary policy measures-, and Europe more concerned about pushing the breaks and innovating only with caution ${ }^{7}$. As stressed by Blanchard: "Rethinking and reforms are both taking place. But we still do not know the final destination, (...) We have a general sense of direction, but we are already navigating by sight.” (Blanchard, 2013).

The IMF has undertaken an interesting initiative to debate where the new orthodoxy is converging by holding high level conferences with renowned academics and policy makers on the margins of the Spring International Monetary and Financial Committee (IMFC) ${ }^{8}$. Usefully, Blanchard, DellÁriccia, and Mauro (2013) have summarized the status of the debate on fiscal, monetary, and the new macro-pillar of macroprudential policies (Box 1 reflects the main conclusions; section 2.2 further develops IMF's approach to structural and social poli(ies) ${ }^{9}$.

It should be noted, that the changes are incremental, leading to an adaptation of the old consensus ${ }^{10}$. As Babb (2012) puts it, there is not a shift in paradigm, at least not in the sense of Hall (1993), of the rising of a competing paradigm with a new hierarchy of goals and instruments. The core precepts of the Washington consensus are retained, but redefined to better cope with the cycle and include the target of financial stability: prudent macroeconomic policies -albeit recognizing the effectiveness of expansionary policies in the short run-; open economies -while admitting the need for capital controls-; and free market capitalism, but recovering the need for regulation and strong surveillance to

\footnotetext{
${ }^{7}$ See Cerón (2012) for an analysis of the limited countercyclical use of fiscal policy over the past four decades, under the primacy of other objectives such as consolidation or economic development.

8 The Fund has hosted such high level conferences in April 2012 and 2013 on "Rethinking Macroeconomic Policy", and in April 2014 on "Monetary Policy in the New Normal" (IMF 2014).

${ }^{9}$ Other IMF's core documents that are shaping this new theoretical apparatus are: IMF (2010a, 2012c, 2014a), Blanchard and Leigh (2013), Bayoumi et al. (2014), Viñals et.al. (2013).

${ }^{10}$ See Moschella (2010) for an overview of the gradual changes in the consensus since the 1990s.
} 
cope with market failure (particularly in the financial system) ${ }^{11}$. What is emerging is less of a new transnational policy paradigm, and more of a policy oriented framework that flees from monochromatic recommendations and leaves margin for country-specific policies.

Box 1

Macroeconomic policy in the post-crisis

\begin{tabular}{|c|c|}
\hline Challenges & Post-crisis \\
\hline \multicolumn{2}{|c|}{ Monetary Policy } \\
\hline $\begin{array}{l}\text { Pre-crisis monetary policy was largely based on one } \\
\text { inflationary target, and one instrument, the policy rate, } \\
\text { and the "divine coincidence" that a stable inflation would } \\
\text { keep economy close to its potential. In the post-crisis } \\
\text { the relation between output gap and inflation has } \\
\text { proven to be weaker (it remains to be seen whether this } \\
\text { is a long term trend). Further, under the liquidity trap } \\
\text { economies can hit the zero bound on nominal interest } \\
\text { rates earlier than expected, losing the effectiveness of } \\
\text { the policy rate, thereby requiring the use of other } \\
\text { unconventional instruments such as quantitative and } \\
\text { targeted easing, liquidity provision to non-banks and to } \\
\text { sovereigns, or managing expectations through forward } \\
\text { guidance. }\end{array}$ & $\begin{array}{l}\text { There has been a bouleversement of targets and } \\
\text { instruments. The post-crisis monetary policy has to } \\
\text { decide among multiple targets -inflation, growth, } \\
\text { financial and external stability-, and using multiple } \\
\text { instruments -policy rate, foreign exchange intervention, } \\
\text { unconventional policies, and capital controls-. On the } \\
\text { targets, positions range from the unemployment-rate- } \\
\text { weary US Federal Reserve (FED), to the inflation and } \\
\text { policy-rate-pass-through guided European Central Bank } \\
\text { (ECB), with the Fund closer to the FED proposals. On } \\
\text { instruments, there is certain consensus on the need to } \\
\text { recourse to unconventional policies, now of widespread } \\
\text { use; the question is the extent and calibration of their } \\
\text { use. }\end{array}$ \\
\hline \multicolumn{2}{|c|}{ Fiscal policy } \\
\hline $\begin{array}{l}\text { The fiscal policy challenge is to strengthen its counter- } \\
\text { cyclical role, notwithstanding the need for medium-term } \\
\text { consolidation. On the debt levels, the post-crisis has } \\
\text { brought about the risk of multiple equilibria depending } \\
\text { on investors' confidence, with high (or low) levels of } \\
\text { debt coexisting either with high or low interest rates (as } \\
\text { seen in the sovereign spreads of peripheral Europe } \\
\text { suddenly dropping after the ECB's commitment to } \\
\text { intervene in August } 2012 \text { with Outright Monetary } \\
\text { Transactions, OMT). On the pace of consolidation to } \\
\text { minimize the negative impact on growth, the Fund has } \\
\text { been particularly active, arguing that the post-crisis } \\
\text { multipliers are larger than in normal times, well above } 1 \\
\text { (compared to the } 0.5 \text { pre-crisis average, Blanchard and } \\
\text { Leigh, 2013). }\end{array}$ & $\begin{array}{l}\text { In practice the margin for managing debt levels and } \\
\text { consolidation has largely been determined by market } \\
\text { pressures and differences in sovereign debt yields. The } \\
\text { debate on fiscal multipliers is still ongoing. There is also } \\
\text { a policy mix debate on how monetary policy can con- } \\
\text { tribute to a smoother consolidation by fostering infla- } \\
\text { tionary debt reduction and low or even negative real } \\
\text { interest rates, which confronts central banks with an } \\
\text { additional dilemma on fiscal dominance. There is more } \\
\text { consensus on the structural fiscal policy, the active } \\
\text { contribution by the Fund fostering measures such as: } \\
\text { independent fiscal councils cyclically adjusted fiscal } \\
\text { rules, early reform of entitlement policies, or reinforcing } \\
\text { automatic stabilizers on the revenue side (IMF, 2014a). }\end{array}$ \\
\hline \multicolumn{2}{|c|}{ Macroprudential policy } \\
\hline \multicolumn{2}{|c|}{$\begin{array}{l}\text { The challenge is to develop the tools and the institutional design of macroprudential policy to cope for financial } \\
\text { stability. The tools are numerous, including instruments to modulate lenders behavior -such as dynamic provisioning } \\
\text { or cyclical capital ratios-; borrowers behavior -loan-to-value or debt-to-income ratios-; or capital controls, where the } \\
\text { Fund has been particularly proactive, including a rebranding as "capital flow management tools" to reflect a more } \\
\text { positive approach from the previous pure advocacy of free capital movements (IMF, 2012d). On the institutional } \\
\text { design, the question is where to allocate the macroprudential authority, as in practice, there is no clear-cut bi- } \\
\text { univocal allocation of macroprudential and monetary policies, respectively with financial stability and monetary } \\
\text { policy. While still under debate, the probable way forward is to place them under central bank authority, which } \\
\text { introduces the challenge of and building up double Chinese walls to separate the MIP, the MAP, and the MOP } \\
\text { (micro and macroprudential, and monetary policies, terminology attributed to Avinash Dixit). }\end{array}$} \\
\hline
\end{tabular}

Source: Blanchard et al. (2013).

${ }^{11}$ Notwithstanding, development theories continue to promote additional considerations within a wide spectrum, going from a revised theories of national industrialization (Lin 2012), to revised institutionalism (Acemouglu and Robinson, 2012). 


\subsection{Quotas [and the Board]}

\subsubsection{What has been done? Historical change to address the legitimacy challenge (once the XIV ${ }^{\text {th }}$ General Review of Quotas becomes effective)}

Since the late 90s there had been an intensified debate on the lack of legitimacy of the IMF. There was an increased disconnection of EMDCs with the Fund due to a sense of lack of evenhandedness -with a harsher treatment by the Fund on their economies ${ }^{12}$-, and most importantly, because of their lack of weight in the decision making process. In practice, IMF quotas (and hence voting power) did not reflect the countries weight in the world economy for two main reasons. First, the inadequacy of the quota formula, basically unchanged since the original 1947 Bretton Woods scheme, and no longer a good (or at least, no longer a generally-accepted) reflection of countries' economic weight.

This problem is largely addressed with the 2008 quota formula ${ }^{13}$,

$$
\mathrm{Q}_{\mathrm{C}}=(0.5 * \mathrm{Y}+0.3 * \mathrm{O}+0.15 * \mathrm{~V}+0.05 * \mathrm{R})^{\mathrm{k}}
$$

which shifts the weights on the variables from the external sector indicators to a GDP-blend variable (a weighted 60/40 percent valuation of the GDP at market rates and purchasing power parity, respectively), and thereby benefiting EMDCs (IMF, 2008) ${ }^{14}$.

Second, the perverse system of actualization of quotas, whereby an 85 percent majority is required to approve quota increases, and the option of reducing them, can only be achieved prior consent of each individual country. In practice, successive quota increases over decades had been largely distributed according to the country's existing quota at the particular moment in time -the so-called equiproportional distribution (and less according to the formula, or the so-called selective distribution)-, resulting in a path-dependency of quotas and a maintenance of the statu-quo in voting power. In consequence, the economies with

${ }^{12}$ Asian economies had criticized the IMF's rigidity in handling the capital account crisis in the late 90s (IEO, 2003). In 2005 Brazil and Argentina paid off their debts to the IMF, bringing the Fund to record-low lending levels and questioning its relevance as a rescue institution.

${ }^{13}$ Source: IMF (2008). QC: calculated quota share. Y (GDP variable): weighted GDP converted at market rates (0.60) and PPP (0.40) exchange rates, averaged over a three year period. O (openness): annual average of the sum of current payments and current receipts for a five year period. V (variability): variability of current receipts and net capital flows measured as a standard deviation from the centered three-year trend over a thirteen year period. R (reserves): twelve month average over a year of official reserves. $\mathrm{k}$ : a compression factor of 0.95.

${ }^{14}$ The GDP variable is given the highest weight in the formula (0.5), above the external sector indicators (openness, 0.3 and variability, 0.15 , and reserves 0.05 ). The economic weight of the country becomes the primary determinant of the voting power compared to the five previous formulas, when the approximate weight of GDP (then measured at market rates) was 29 percent, compared with estimated percentages of approximately 50, 14 and 7 corresponding to openness, variability and reserves, respectively (IMF 2006). 
higher growth over the last 30 years, i.e., a large number of EMDCs, have seen a growing under representation in the IMF relative to their economic weight, and hence a loss of IMF's legitimacy.

This problem was addressed with the successive quota increases of 2006, 2008 and especially with the XIV ${ }^{\text {th }}$ General Review of Quotas (GRQ or Review) in 2010, which doubled the quotas up to approximately US\$700 billion, and established a distribution in favor of the most dynamic emerging countries and those countries more underrepresented under the new 2008 formula. Once implemented (the US ratification is still pending), it will result in a historical correction of a misalignment inherited from the very foundation of the Fund ${ }^{15}$.

\subsubsection{What can be done? Complete the $X I V^{\text {th }}$ Review, and a slim margin for fine-tuning the formula and an ad hoc increase [and the Board]}

The debate on quotas is not yet closed. First, the US Congress has to ratify the $\mathrm{XIV}^{\text {th }}$ Review. And second, EMDCs claim that even after the 2010 quota increase, they remain underrepresented, including because the 2008 formula is still not an adequate reflection of economic weight (Nogueira-Batista 2013). Actually, at the time of the 2010 decision, the G20 and the Board of Governors already projected a new review of the formula by January 2013 (concluded with no change), and a new GRQ by January 2014, which is now being pushed forward to a XV ${ }^{\text {th }}$ Review to be concluded in 2015 (G20, 2010).

Ideally, on the what-should-be-done side, a more automated system could be established where actual quotas would adjust over time (in the quinquennial GRQ) according to the weights as measured by an agreed quota formula. On the what-can-be-done side, the margin is slim for two main constraints: First, the small political room for negotiation after a very long lasting debate on quotas. The 2008 formula is the result of a $2^{\text {nd }}$ round debate in 2006-08, after a notable failed attempt on the discussions held between 2000 and 2003 around the Copper report (IMF, 2000), which nonetheless contributed to build an increasing sense of urgency to correct the lack of legitimacy in the Fund.

Further, the new formula implies changing a 60-years-old system inherited since the inception of the Fund, which turned into a complicated five-formula system after some adjustments in 1963 and 1983, but basically revolving around the original Bretton Woods Formula. Hence, the 2008 formula has provided a certain sense of big success; albeit not closure, as EMDCs (particularly the BRIC) have not sealed it as an end deal in 2010. The new formula is not perfect, but is a significant achievement that breaks historical inertia, importantly, by placing the GDP as the main variable in the formula and including a purchasing

${ }^{15}$ See Moreno (2013) for a detailed analysis of the 2008 quota formula and the 2006, 2008 and 2010 quota increases. 
power parity component (a long standing claim by EMDCs). The result is that advanced economies reduced their calculated overall quota weight by 12 percentage points, down to 56 percent ${ }^{16}$.

The second constraint is the lack of political interest of the US Congress. The 2010 quota reform has not been applied yet because the US Congress has failed to ratify it. The non ratification is somewhat surprising as it does not imply more taxpayer's money to the Fund, but allowing shifting into quotas near 60 percent of the US\$ 100 billion already approved by Congress for the New Arrangements to Borrow (NAB) in 2009. In terms of voting power, the US retains its veto power and the main shift is from the European countries in favor of EMDCs voting power. Certainly EMDCs would formalize higher political power (with the BRICS close to veto power), but this is already a fait accomplie in the Board discussions -the weight of EMDCs is clear in policies such as the capital controls, the FCL, or maintaining alive the quota debate-, and with their veto power in activating the NAB, which is currently supporting Fund's resources. This probably reveals the lack of interest of Congress; the Fund is certainly not in its priorities, and if anything, it is used for partisan struggles. But there is probably also a failure of the Administration in terms of insufficient communication and not pushing the Fund agenda strongly enough (Truman 2014, and The Economist, 2014).

Given these political constraints, the most likely outcome is: the ratification of the XIV ${ }^{\text {th }}$ Review -the April 2014 IMFC and G20 meetings have jointly made the strongest call yet for the US to ratify it (IMFC, 2014; G20, 2014)-, and no change in the $\mathrm{XV}^{\text {th }}$ Review in 2015, nor in the formula. This being said, and considering that the G20 has yet to deliver something from its commitment to review the formula and the quotas, the margin for maneuver would most likely move around an ad hoc quota increase for most underrepresented countries along the lines of the 2006-08 increase -that is targeting countries with larger negative values on column q1-q3 in Table 1, with China being the main candidate as the most underrepresented country-, and a slight modification of the formula.

Beyond conceptual considerations, the debate on the formula will likely continue around the current variables, as "they are already there" and it is more difficult to reach a new consensus on "better" variables ${ }^{17}$. The main opposite

${ }^{16}$ This including Singapore and South Korea in the group of dynamic EMDCs (instead of advanced), considering that in terms of IMF governance they are probably better placed in the side of the traditionally underrepresented Asian economies. Data from IMF (2013b,c).

${ }^{17}$ Probably a measure of integration in the global capital markets is better proxy than the current measure of openness (sum of current payments and receipts basically) to the ability to contribute to the Fund's finances and a member's stake in the global economy and global financial stability. But there are data limitations, the methodology could always be questioned, and it 
positions go from the EMDCs defense of higher weight for the GDP (and its ppp valuation) and the Europeans strong defense of openness (with weaker defense across the membership of variability and reserves). Interestingly, the current formula (q3 in Table 1) weights the groups of advanced and emerging economies nicely in the middle of the measurements by GDP at market prices (q4) and at ppp (q5). A midpoint for the formula could be to eliminate variability and reserves variables and provide their weight equally to GDP blend and openness (q6), an scenario where large EMDCs increase their calculated weight (i.e. a positive number in column $\mathrm{q}_{7}-\mathrm{q}_{3}$ ).

One final note on the Board and Management. The real importance of the changes in quotas is their reflection in Board representation in an institution where there is a tradition of consensus-based decisions. Board representation determines the weight of the country in the day-to-day business, for which is key to hold the position of Executive Director (ED), the largest the quota, the largest the options to hold the ED position in constituency negotiations. Here, the EU has committed to reduce by 2 the number of ED of advanced European countries, thereby reducing the traditional European "rolling pin" in the Board meetings. Europe has so far reduced by 1.62 the ED positions, but mainly for the benefit of non-advanced European countries ${ }^{18}$. Following Camdessus et al. (2011), it would be good to take advantage of the changes in the Board to seek a rapprochement between the compositions of the Board (and hence the IMFC) and the G20 to ensure consistency between the two forums ${ }^{19}$. Finally, it will be important that, for the first time, the next Managing Director of the Fund is a non-European, and from an emerging country.

could imply significant shifts in country's weights. The current measures are the least of evils with the advantage of being already there. For a detailed discussion on variables see IMF (2012e).

${ }^{18}$ The merger of the Netherlands and Belgian "chairs" has deliver 1 seat for Eastern Europe and Turkey; Switzerland has freed 0.5 in favor of Poland, and the Nordic chair has freed 0.12 in favor of Baltic countries.

${ }^{19}$ The first joint IMFC-G20 meeting in April 2014 is a clear reflection of the problems of having two parallel forums. For a more detailed analysis of Board reform see Moreno (2013, Chapter 4). 
Table 1

IMF quotas: alternative scenarios for top-25 countries (percentages)

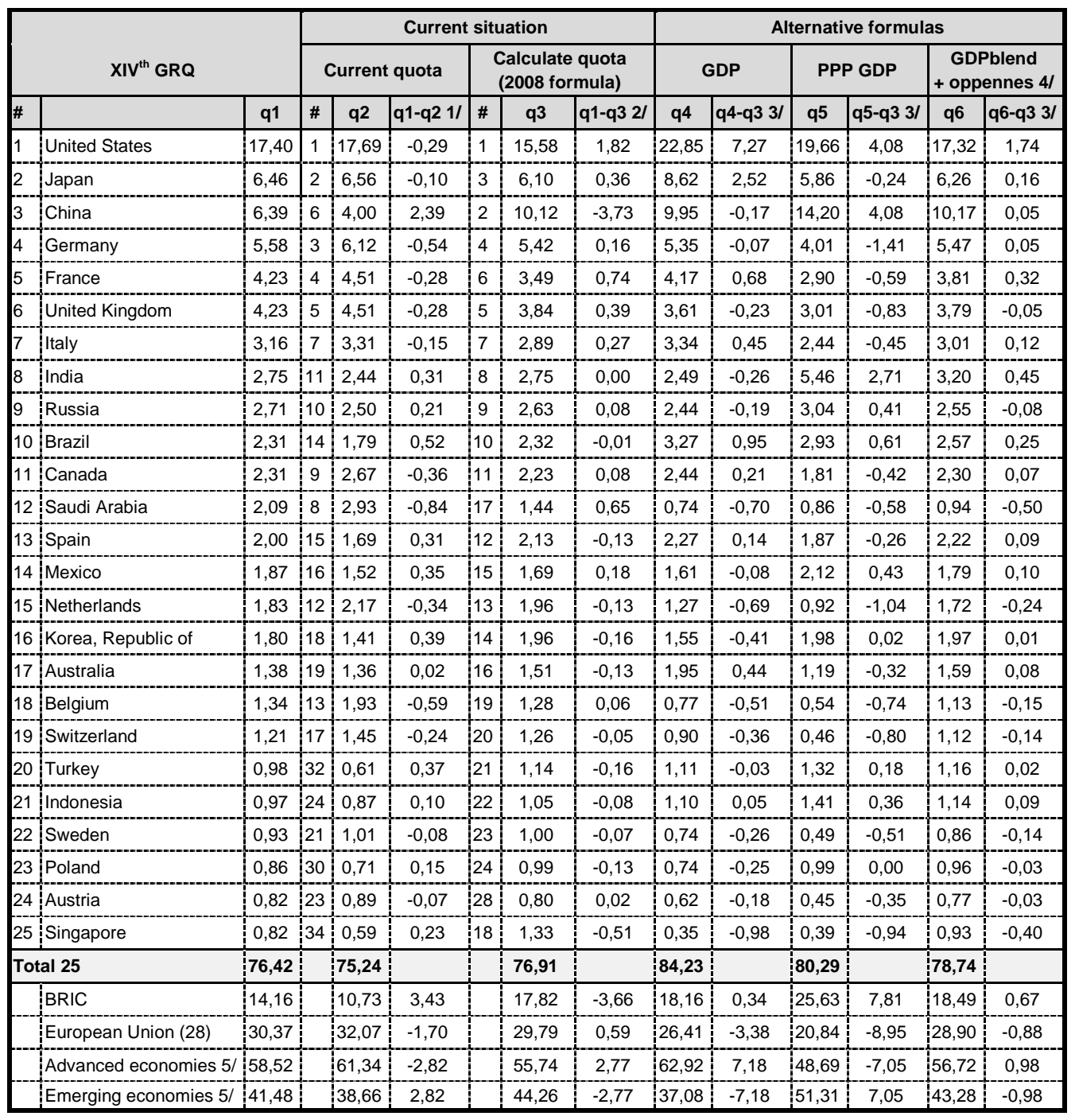

1/ Increase in quota after the XVth Review.

2/ Level on misalignement after the XVth Review.

3/ Improvement ( + ) with respect to 2008 formula.

4/Formula: $0.625 *\left(0.6^{*} G D P+0.4^{\star} P P P\right.$ GDP $)+0.375^{*}$ Openness; Compression factor: 0.95 .

$5 /$ Using the WEO country classification, although including South Korea and Singapore in the group of emerging economies.

Source: Data based on IMF (2013b, c) and IMF (2008). 


\section{SURVEILLANCE}

\subsection{What has been done? Decisive move towards an integrated surveillance}

The global financial crisis has revealed significant challenges in the Fund's surveillance. The Fund itself has outspokenly reviewed the shortcomings of the pre-crisis surveillance through staff policy papers and different reports by the $\mathrm{IEO}^{20}$-a good practice of transparent institutional review (lacking, for instance, in the EU)-. The main themes of the drawbacks include: (i) a country-based surveillance that did not keep up with an increasingly interconnected global economy, which requires a more systemic perspective and a greater focus on spillovers; (ii) insufficient financial sector surveillance and institutional expertise at the time of a global financial crisis; (iii) deficit of evenhandedness and traction, with lighter treatment and impact on advanced economies ${ }^{21}$; (iv) institutional capture favoring markets; and (v) a too general assessment of risks and insufficiently linked to policy recommendations.

Since 2009, the fund quickly moved from a surveillance traditionally centered on a bilateral macroeconomic and balance of payments analysis, into a more integrated approach that links the multilateral and bilateral surveillance, and strengthens financial surveillance; which is reflected in traditional reports but also in the development of a large new set of surveillance reports (see Table 2). Further, the 2011 Triennial Surveillance Review (TSR, IMF 2011a), introduced five operational priorities applied across the board that have become the standard to analyze Fund's surveillance, namely: interconnectedness, risk assessment, financial stability, external stability, and traction (box 2 summarizes the main changes under these categories).

This new approach is formalized in 2013 with the approval of the Integrated Surveillance Decision. The ISD comes after the insufficient progress to account for spillovers and interconnectedness of the 2007 Decision on Bilateral Surveillance -which did not nonetheless provided a long-overdue update of the 1977 Decision to account for external stability ${ }^{22}$-, and the failed attempt to introduce a multilateral surveillance decision (IMF 2010b).

${ }^{20}$ Including IMF (2010b, 2011a, 2012c); IEO (2011, 2013). Box 1 in IMF (2011a) summarizes the main reports produced between 2009 and 2011.

${ }^{21}$ The positive evaluation of the UK, Belgian and Iceland FSAP, or not having conducted an FSAP in the US, where the subprime crisis originated is commonly referred to.

22 The 2007 Decision introduced external stability as a central principle for bilateral surveillance, including the analysis of both the current and the capital accounts of the balance of payments, and introducing the concept of fundamental exchange rate misalignment (thereby delinking the analysis of exchange rate manipulation from the purpose of the authorities). For an analysis of its implementation See Vasishtha and Lavigne (2010). 
In order to get the necessary support, the ISD stops short of changing individual country obligations under Article $\mathrm{IV}^{23}$, or from shifting the focus of their policies from their primary objective of their internal stability (albeit being mindful of their impact on third countries and global stability). But it does endorse the analysis of spillovers and the use of Article IV consultations as vehicle for multilateral surveillance, and sets out the modalities of multilateral surveillance, including the option of multilateral consultations ${ }^{24}$ (IMF, 2012f).

\section{Box 2}

Operational priorities of the Fund's surveillance

Interconnectedness

Cross-border spillover analyses (inward and outward) are a regular feature in bilateral and multilateral surveillance for globally or regionally systemic countries. The Fund has also introduced new reports such as: the spillover reports, conducted in parallel to Article IV reports for systemic economies (with five pilot reports for China, the US, Japan, UK and Euro Zone); the Sustainability Assessments for G-20 Mutual Assessment Process (MAP), cluster consultations (of a group of countries) and thematic reports, which emphasize cross-country analysis (e.g. reports on financial interconnections, transnational financial institutions, or compared labor markets).

\section{External stability}

The traditional exchange rate analysis has been extended to capital flows, balance sheet positions, reserves adequacy, discussions on external competitiveness, or the consistency of the current account with medium-term fundamentals. There is also new methodological tools and new reports such as the External Balance Assessment (the EBA, introduced in 2012 building on the Consultative Group on Exchange Rates or CGER methodology); or the new Pilot External Sector Report (ESR) covering the world's largest economies that assesses the joint consistency of members' external balances, currencies, and policies.

Financial stability
The Fund has developed a Financial Surveillance strategy based in three pillars (IMF, 2012c): improving risk identifi-
cation and macrofinancial policy analysis; upgrading the instruments and products of financial surveillance; and
increasing the traction and impact by engaging more actively with stakeholders. Financial surveillance has been
strengthened in Article IV reports and regular -at least every 5 years- Financial Stability Assessments (FSA) for
countries with systemic financial systems, including an EU FSAP. A number of initiatives have improved financial
information (overcoming the traditional reluctance by authorities) including: development of the SDDS plus (Special
Data Dissemination Standard) with enlarged financial data requirements (IMF 2012g), or the joint IMF/FSB G-20
Data Gaps Initiative.
Risk assessments
Risk assessment matrices are now common in Article IV reports, as well as external sector vulnerability exercises for
advanced and emerging economies (VEA, VEE), previously only used for the latter. The Fund also conducts a
semiannual Early Warning Exercise (EWE), jointly with the FSB that complements the GFSR and WEO identifying
tail risks and vulnerability scenarios and is presented in a restricted format to Ministers and Governors.
Traction
The Fund has increased its outreach, including through more continued consultations with country authorities,
strengthened bilateral interaction with key market and economic expert's participants, and higher interaction with the
media. There has also been an effort for streamlining reports and focusing on key messages, including with the new
report on the Global Policy Agenda, which sets the agenda for the IMF's key priorities by integrating the main
findings of the WEO, GFSR Fiscal Monitor, and Pilot ESR and Spillover Reports.

Source: IMF (2011a), IRC-TF (2014), Moreno (2013).

${ }^{23}$ Article IV of the Fund's Articles of Agreement provides the legal basis for bilateral (section 1) and multilateral (section 3) surveillance (IMF, 2011b).

${ }^{24}$ Multilateral consultations focused on global imbalances had a first failed-attempt in 2006 (IMF, 2007). 


\subsection{What more can be done? Calibrating surveillance}

In 2014 the IMF is conducting a new TSR, which will be structured around two themes: the effective implementation of the integrated surveillance framework and the five operational priorities, and the consistency and focus of the policy advice (IMF, 2013d). The tools for the post-crisis surveillance are already there. Again, within a generally well-structured surveillance framework, the main challenge is the refinement of areas where the Fund has maybe gone too far (risk assessment), or there is room for further advancing (structural analysis, inter-institutional coordination). Here, we would stress five interrelated areas:

(i) Analysis of structural reforms and the social dimension of policy advice. The Fund is looking at whether and how to improve its structural analysis -particularly of the labor market- now limited to general and vague recommendations. The analysis of structural reforms is indeed necessary as they are increasingly critical for macro-performance, even more so when macroeconomic policies are constrained by market behavior or by transnational rules (particularly in the EU) ${ }^{25}$. For the same reason, the IMF should increasingly look at social issues such as inclusive growth, inequality, and health and education outcomes, as they have macroeconomic implications. In this respect, the Fund is already building a body of policy approach to inequality and social dimension of growth (Ostry et al. 2014).

Here, it is important to stress two aspects: first, the Fund should take advantage of the expertise of third organizations, especially the Organization for Economic Co-operation and Development (OECD), the World Bank, and the International Labor Organization (ILO) -to which the Fund has shown little receptiveness-. Second, the need for an incremental approach, i.e., developing structural reform or social dimension expertise can only be achieved with time. Such was the case for financial expertise, which started to develop at the end of the $90 \mathrm{~s}^{26}$, by creating new departments and it was only brought "up-to-par" with traditional core areas of surveillance in the post crisis (see Gola and Spadofora, 2009, and Moschella 2011). In this process, it is important to enlarge the staff's multidisciplinary background beyond macroeconomic and financial expertise, into sectoral, and even development economics and political science experts (Momani and Lanz, 2014).

(ii) Counter-cyclicality on risk assessment. In a pendulum-like swing, the Fund has gone from mild risk assessment usually hidden in the reports, to ex-

25 The Australian G20 presidency is also trying to shift the scope of the Framework for growth from macroeconomc policies to medium-term structural issues (G20, 2014).

${ }^{26}$ Gola and Spadafora (2009) place the preliminary stages of the financial sector surveillance in the technical assitance work related to the banking crisis of the 80s. 
plicit clearly-displayed and quantified analysis (mainly through risk matrices and scenario analysis), following a sort of risk aversion of being caught in not predicting the next crisis after failing with the global financial crisis. Notwithstanding the importance of the Fund being outspoken on the risks, there is margin for less emphasis on the quantification -especially given the caveats to which all methodologies are subject to-, and more into qualitative analysis and specially the policy recommendations to manage risks, thereby avoiding ratingagency-type of analysis. Further, there is room for the IMF having an explicit countercyclical approach to risks, i.e., nuancing (within the general trend) markets views of excessive confidence or excessive risk attached to a country.

(iii) Communication strategy and Fund's accountability. Under the operating principle of traction, the Fund has significantly increased its interactions with the media and streamlined its reports to make them more reader-friendly, including increasingly powerful visual presentations ${ }^{27}$ (maybe too much, as there seems to be a growing institutional culture in search of the "headline"). Here, it is important to take into account the trade-off derived from the Fund's dual role as a watchdog and a trusted advisor to the authorities (traditionally, candor vs. transparency trade-off, IMF, 2005). Lately, the Fund seems to be shifting to the watchdog side with increasing accent on risks and contacts with markets, experts and press; risking its traditional role as trusted advisor, necessary to hold a candor, off-the-record, dialogue with the authorities. Here, it will be important that the Fund works closely with the authorities to design a customized countryspecific outreach strategy (IEO, 2013). On accountability, further progress could be achieved by including in the reports a box on the Fund's past advice and whether it has been modified, as well as alternative views by staff and third experts (Leipold 2014, Broome 2014).

(iv) Reforming the Euro area report. The euro area has large specificities for the purposes of the Fund's surveillance, most notably the single monetary policy, the stability and growth pact -which limit national room of maneuver-, and a complex decision-making structure with Brussels delivering economic regulations to be nationally applied. The Fund has significantly improved its European surveillance to account for this reality ${ }^{28}$, however, following PissanyFerry et. al (2011) and Kruger et.al. (2014), there is scope for reforming the current Euro area policies report into surveillance exercise of the euro area as an integrated economy -beyond the current general summing up of spillovers-, including a comprehensive discussion of euro area policy elements with union and national authorities.

\footnotetext{
${ }^{27}$ As a side note, departments have been equipped with new computers with more powerful slide presentations software.

${ }^{28}$ IRC-TF (2014) provides a detailed analysis of the Fund's surveillance in Europe.
} 
Table 2

Surveillance reports for a large EU country

\begin{tabular}{|c|c|c|c|c|c|c|c|}
\hline \multirow[b]{2}{*}{$\begin{array}{c}\text { Report } \\
\text { (- new since 2009) }\end{array}$} & \multirow[b]{2}{*}{ Frequency } & \multicolumn{6}{|c|}{ Topics treated } \\
\hline & & Macro & $\begin{array}{l}\text { Macro- } \\
\text { financial } \\
\text { linkages }\end{array}$ & $\begin{array}{l}\text { Financial } \\
\text { sector }\end{array}$ & Risks & $\begin{array}{l}\text { Str. } \\
\text { issues }\end{array}$ & $\begin{array}{l}\text { External } \\
\text { balances }\end{array}$ \\
\hline \multicolumn{8}{|l|}{ Bilateral: } \\
\hline Article IV & Annual & $x$ & $x$ & $x$ & $x$ & $x$ & $x$ \\
\hline - Spillover reports & Annual & $x$ & $x$ & & $x$ & & \\
\hline FSAP & $\begin{array}{l}\text { Every } 5 \\
\text { years }\end{array}$ & & $x$ & $x$ & $x$ & & \\
\hline ROSC $^{1 /}$ & $\begin{array}{l}\text { Every } 5 \\
\text { years }\end{array}$ & & & $x$ & & & \\
\hline \multicolumn{8}{|l|}{ Multilateral: } \\
\hline $\begin{array}{l}\text { - Global Policy } \\
\text { Agenda }\end{array}$ & Twice a year & $x$ & $x$ & $x$ & $x$ & & $\mathrm{x}$ \\
\hline WEO & 4 times $^{21}$ & $x$ & $x$ & & $x$ & & $x$ \\
\hline GFSR & Twice a year & & $x$ & $x$ & $x$ & & \\
\hline$-F M$ & Twice a year & $x$ & & & $x$ & & \\
\hline - EWE/VEA & Twice a year & $\mathrm{x}$ & $x$ & $x$ & $x$ & & $x$ \\
\hline $\begin{array}{l}\text { - External Sector } \\
\text { Report }\end{array}$ & Annual & $x$ & & & $x$ & $x$ & $\mathrm{x}$ \\
\hline - G20 MAP-related & Twice a year & $x$ & $x$ & & $x$ & $x$ & $x$ \\
\hline \multicolumn{8}{|l|}{ Regional: } \\
\hline $\begin{array}{l}\text { Euro area policies } \\
\text { report }\end{array}$ & Annual & $x$ & $x$ & $x$ & $x$ & $x$ & $x$ \\
\hline $\begin{array}{l}\text { - Clustered } \\
\text { consultations }\end{array}$ & Annual & $x$ & $x$ & $x$ & $x$ & $x$ & \\
\hline $\begin{array}{l}\text { - Cross-country } \\
\text { reports }\end{array}$ & $\begin{array}{c}\text { Several a } \\
\text { year }\end{array}$ & $x$ & $x$ & $x$ & $x$ & $x$ & $\mathrm{x}$ \\
\hline TOTAL/year & $18^{3 /}$ & & & & & & \\
\hline
\end{tabular}

1/ ROSCs cover several other areas apart from financial sector, such as data and policy transparency, and market integrity.

2/ Two WEO in Spring and Fall and two WEO updates is winter and summer.

3/ Total number of reports (excluding FSAPS, ROSCS, and clustered and cross-country reports) that a large euroarea country is normally subject to, each year.

Source: Updated from IRC-TF (2012).

v) Intra and inter-institutional coordination. Reports have proliferated in the post-crisis, both within the Fund and in international (FSB, OECD, G20) and regional (mainly in the EU) surveillance initiatives. This has created an international surveillance spider's net, which raises the risk of duplication and inconsistency in the messages, as well as loss of traction due to an overabundance of non-clearly prioritized messages. There is margin for streamlining IMF reports, for instance, only on IMF assessments, a large euro-area country could be "on the press" more than 18 times a year (see Table 2). It will be important to develop adequate internal coordination (not so clear between country and multilateral report teams ${ }^{29}$ ) and inter-institutional cooperation, with at a minimum, exchange of information flows, with room for joint or distribution of reports

${ }^{29}$ For instance, the 2011 and 2013 GFSR included financial capital needs estimates in European countries, raising concerns and controversial methodologies that were not reflected in bilateral or euro area reports, the more natural place for this type of analysis. 
considering comparative advantages, especially with the G20 MAP and the FSB.

\section{LENDING POLICY AND RESOURCES}

\subsection{What has been done? Solid toolkit of lending instruments with solid enough resources}

Probably the most significant change in Fund policies has been the reforms of its lending instruments, which can be synthesized in three key changes: (i) a more flexible crisis resolution policy, (ii) a new insurance lending function, and (iii) the parallel buildup of Fund's resources ${ }^{30}$.

The main (i) credit lines of crisis resolution under the General Resources Account (GRA) have been reduced to two: the Stand-by Arrangements (SBA), and the longer-term, Extended Fund Facility (EFF) ${ }^{31}$. These facilities cover any balance of payments difficulties regardless of its origin, thereby eliminating the Fund's tradition of a casuistic of programs depending on the type of distortions. Both facilities are made significantly more flexible in 2009 as they lower their conditionality -including eliminating structural performance criteria, which are converted into benchmarks-; and provide larger and more flexible (frontloaded) access to resources -up to 600 percent of quota and, in practice, above under an also more flexible exceptional access policy-.

With respect to (ii) the new insurance function, there are also two main facilities: the Flexible Credit Line (FCL, since 2009) and the Precautionary and Liquidity Line (PLL, since 2010) ${ }^{32}$. They introduce two critical changes to the Fund's lending policy by eliminating ex post conditionality (or substantially reducing it in the case of the PLL) and replacing it with pre determined eligibility criteria (or ex ante conditionality); and by reinterpreting the balance of payments "need" test, so that a country can subscribe the program because it is subject to the risk of external contagion, but without an actual "need", further with an explicit recognition about its good fundamentals and economic situation (“innocent bystanders") ${ }^{33}$.

${ }^{30}$ For a detailed analyses see Moreno (2013, chapters 2 and 5).

${ }^{31}$ A third crisis resolution line under the GRA is the Rapid Financing Instrument (RFI) that facilitates urgent resources in emergency situations but is limited to $100 \%$ of quota access.

32 The PLL has its precedent on the PCL (Precautionary Credit Line) created in 2010. The Liquidity component is added in 2011, after the failed attempt by the Fund to establish Multicountry Swap Lines (IMF, 2010c). A third insurance facility would be the HAPA (High Access Precautionary Arrangement), which is a high-acces SBA treated as precautionary, i.e., with a program but no intended disbursement of resources.

${ }^{33}$ The legal trick is that the FCL and the PLL are requested when there is not a balance of payments need, but when and if the resources are used because of the contagion, the need has materialized. 
Hence, the Fund changes a 60-year history of programs that were loaded with conditions and with tranche disbursements subject to compliance with the conditionality. Reviews are now more based on an overall assessment of the program progress, and on pre-conditions in the case of insurance facilities. Importantly, the new lending policy can only be understood as a cumulative process of the changes that had been undertaken before, particularly since the mid 90s. For instance, the simplification of conditionality only comes after more than a decade of reinforcement within the Fund of the principles of program ownership by the country authorities, and parsimony or criticality of the measures, in order for the programs to be effective. The larger access limits had their precedent on the large and frontloaded programs of the 90s to cope with the capital account crisis in Asia and Latin America. And the FCL and the PLL had their precedent in the extinct CCL (1999-2003), which was never used because of stigma problems. The crisis is therefore the catalyst to undertake the reforms.

Figure 2

IMF loans 2008-2014

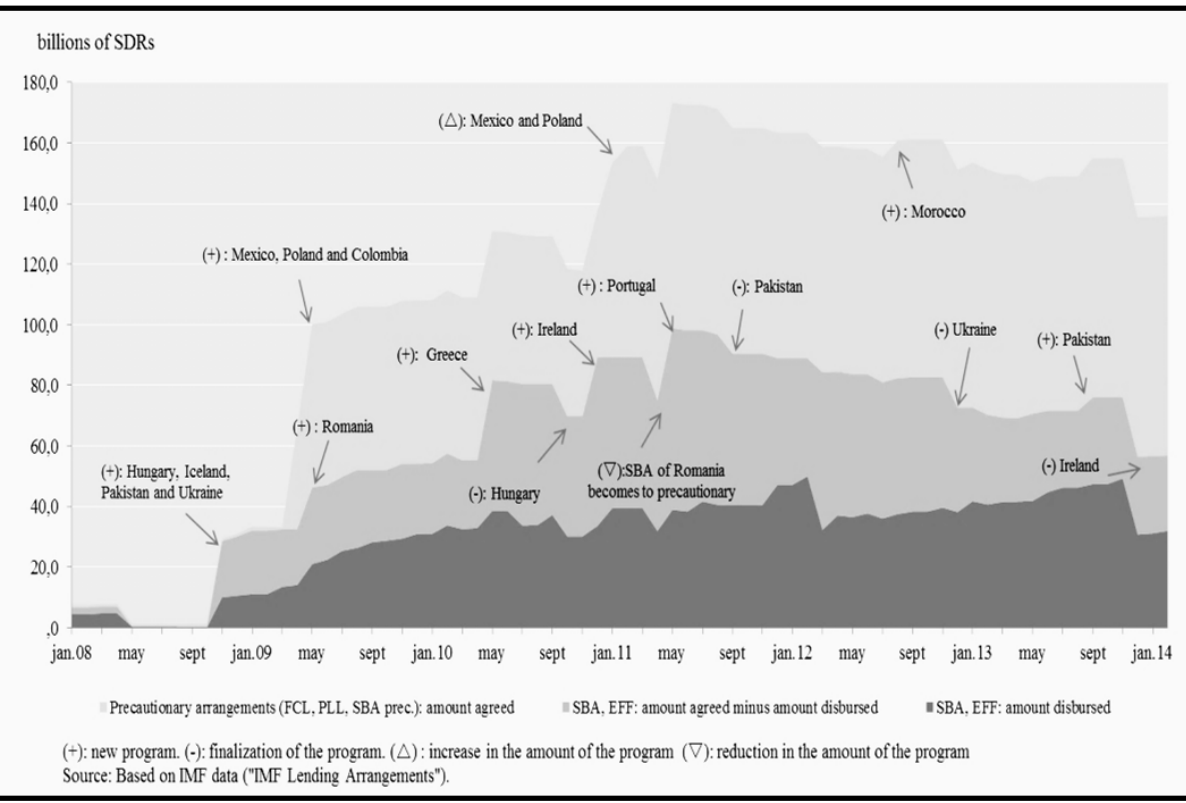

Source: Based on "IMF Lending Arrangements" web page data.

Under this new policy, the Fund was the first to assist Eastern European countries already in 2008, even the European Union (EU) countries in 2010 (jointly with the EU), or most recently in Ukraine. Here, there has been no lack of political negotiation leeway within the Board, such in the cases of Greece - 
where the Fund had to reform the debt sustainability criterion to consider a high risk of international systemic spillovers; or Ukraine, triggering an urgent program driven largely by geopolitical concerns. Starting from historical lows in Fund lending in the summer of 2008, between the fall of that year and December 2013 it has approved programs worth around US\$ 650 billion (SDR 430 billion, adding up renewed programs), of which 57\% are FCL precautionary lines. Figure 2 reflects the yearly value of open loans since the fall of 2008.

(iii) The buildup of resources. The Fund has accompanied the fundamental changes to the lending policy, with an almost quadrupling of its resources since 2009. The increase has been achieved in a sequential manner represented in Table 3: from bilateral resources (two rounds in 2009-2010 and 2012-13), that fold into the NAB (2011), which will partially fold into quotas (once the US ratifies the 2010 quota reform). The Fund has achieved SDR 658 billion (around US\$ 1 trillion) in "quasi-permanent" resource of quotas and $\mathrm{NAB}^{34}$, plus an additional SDR 307 billion, on temporary bilateral loans (for the most part until 2017).

Table 3

IMF General Resource Account. Owned and borrowed resources (millions)

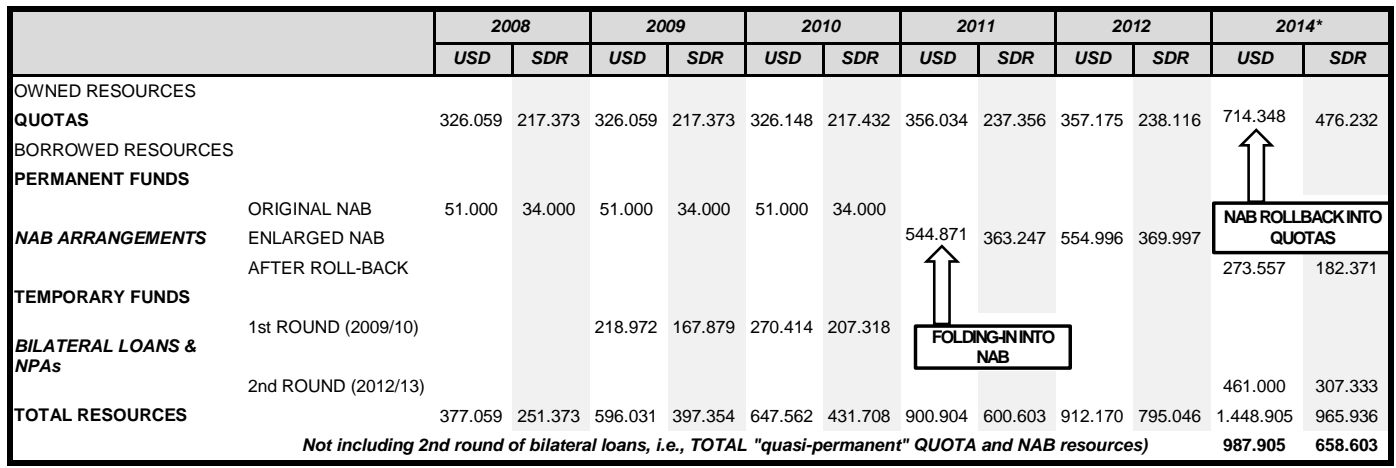

* Pending ratification of quota increase and second round of bilateral loans and NPAs.

Source: L'Hotellerie-Fallois and Moreno (2014).

\subsection{What more can be done? Anchoring the lending toolkit and added flexibility to resources}

The main challenges ahead for the lending policy are determined by the exit from extraordinary expansive monetary and fiscal policies in advanced economies and their spillover risks on emerging countries. The types of country-crisis

\footnotetext{
${ }^{34}$ The quotas paid by the member countries are the IMF's own resources, while the NAB are borrowed funds, albeit quasi-permanent ones, given the implicit commitment by lender countries to renew them automatically.
} 
that can be anticipated are similar to the ones faced since 2009, requiring large rescue and precautionary programs. The Fund has reached a good equilibrium on its toolkit of programs for the time being, once achieved the insurance function provided by the FCL, and the liquidity window of the PLL, that complement the enlarged crisis resolution programs. However, there are three areas where there can be further progress, that are currently under discussion: (i) anchoring precautionary facilities; (ii) dealing with sovereign debt restructuring and private sector involvement (PSI) issues; and (iii) adding flexibility to the resources.

(i) On the design of the precautionary facilities, the debate is centered on whether or not to take steps back, i.e. making their use stricter out of moral hazard concerns. They were reviewed on February 2014, and the main concern was introducing mechanisms for exit strategies -so far, three countries that requested the FCL in 2009 have chained successive renewals since then-, and further requirements eligibility for the FCL. There is a consensus on the Board to keep them as they are with some fine-tuning of the qualification criteria to cope for institutional quality (IMF 2014c). Precautionary facilities constitute a long-awaited success for the IMF and should not be reviewed further, much less in the current state of uncertainty. Further, moral hazard is no longer the primary concern in the design of the lending policy proven well-designed conditionality $^{35}$. If anything there is margin for eliminating the precautionary window of the PLL, as its frontier with the FCL and the HAPA is unclear. However this is not a priority, nor is it in the short term agenda.

(ii) Sovereign debt restructuring and PSI. Once freed from the urgency of program assistance and market reactions, the Fund has relaunched in 2013 (IMF, 2013) an international dialogue on sovereign debt restructuring. The proposals in the current debate are numerous and they recover the traditional statutory versus contractual approaches, ranging from: setting up international tribunals $^{36}$; establishing voluntary coordination regimes ${ }^{37}$; going through reforming Fund programs (IMF, 2013e ${ }^{38}$; to strengthening the contractual approaches, through contingent convertible bonds (COCO's) or GDP-linked bonds (Brooke et al., 2013).

Here, the Fund can learn from the failed attempt of a Sovereign Debt Restructuring Mechanism (SDRM) back in 2003 (Krueger, 2002). The reform-

\footnotetext{
${ }^{35}$ See Moreno (2013, p. 72-76).

${ }^{36}$ Such as the Sovereign Debt Tribunal (SDT) (Paulus, 2010), or the UN's International Debt Restructuring Court (IDRC) (UN, 2009).

${ }^{37}$ Including CIGI's Sovereign Debt Forum (Gitlin et al., 2014), or the IIF's “Principles for Stable Capital Flows and Fair Debt Restructuring” (IIF, 2012)

${ }^{38}$ Such as including automatic bail-in clauses (IMF, 2013c) or creating a new facility linked to debt sustainability (Buchheit et al., 2013).
} 
momentum has improved as there is an increase appetite for some form of bailin and for a predictable legal framework, particularly in view of the historically high Greek debt restructuring and the latest chapters on the long litigation on Argentina's 2001 restructuring, which have tested the effectiveness of CACs and more generally the contractual, market-based approach that has dominated the past decade. Ideally, the assumption of a restructuring process would be articulated through an SDRM-type mechanism; in parallel, the Fund should continue to foster joint institutional-market participant's dialogue at the early stages of the crisis, building on the success of the Vienna Initiative.

(iii) Size of IMF resources. Ideally, the Fund would have unlimited resources acting as a lender of last resort and thereby signaling a strong bazooka to act when necessary (provided political support at the Board). This is however a non-viable option longtime discussed, traceable back to Keynes' bancor supranational currency. As Boughton (2011) has put it when referring to the capacity to generate liquidity through issuing SDR, this option is like the "flight of the Dodo" ${ }^{39}$. The chances that the Fund evolves into an entity with the capability to generate liquidity are remote because there is no political support for a Fund working as a central bank.

This brings the question of the sufficiency of Fund resources and how large should they be. It is difficult to measure what future financial needs might be, certainly key issue will be the future use of the FCL, which is absorbing more than half of the loans ${ }^{40}$. The conventional benchmarks that are commonly used are setting the Fund's size relative to world variables such as the GDP, or specially to international capital flows -even more so in the current high capital volatility context-. As shown in Figure 3 (a), the Fund's quota plus NAB resources are below historical GDP, and especially, capital inflows levels. Again, ideally, the quinquennial GRQ could adjust quotas automatically according to a specific benchmark. But as we have seen, the process of increasing quotas presents huge political constraints due to its governance implications given the multiple nature of quotas (providing fund resources, and determining member's voting power and level of access in programs).

However, there are two main reasons not to be too concerned about the size of the Fund: first, the Fund is not alone. A main characteristic of the last decade is the growth in alternative resources under the so-called Global Financial Safety Nets (GFSN), including the large build up of reserves, bilateral central bank swaps, or the expansion of Regional Financial Arrangements (RFAs), such as the European Stability Mechanism (ESM), the expansion of the CMIM or

\footnotetext{
${ }^{39}$ The Dodo is an extinct bird that could not fly and a symbol in Anglo-Saxon culture of something obsolete or out of place.

${ }^{40}$ For a detailed analysis on Fund resources see L'Hotellerie-Fallois and Moreno (2014).
} 
more recently the BRICS US\$100 fund. As seen in Figure 3 (b), RFAs surpass Fund's resources (when discounting for temporary bilateral loans) ${ }^{41}$.

Figure 3a

Relative size of the Fund's resources

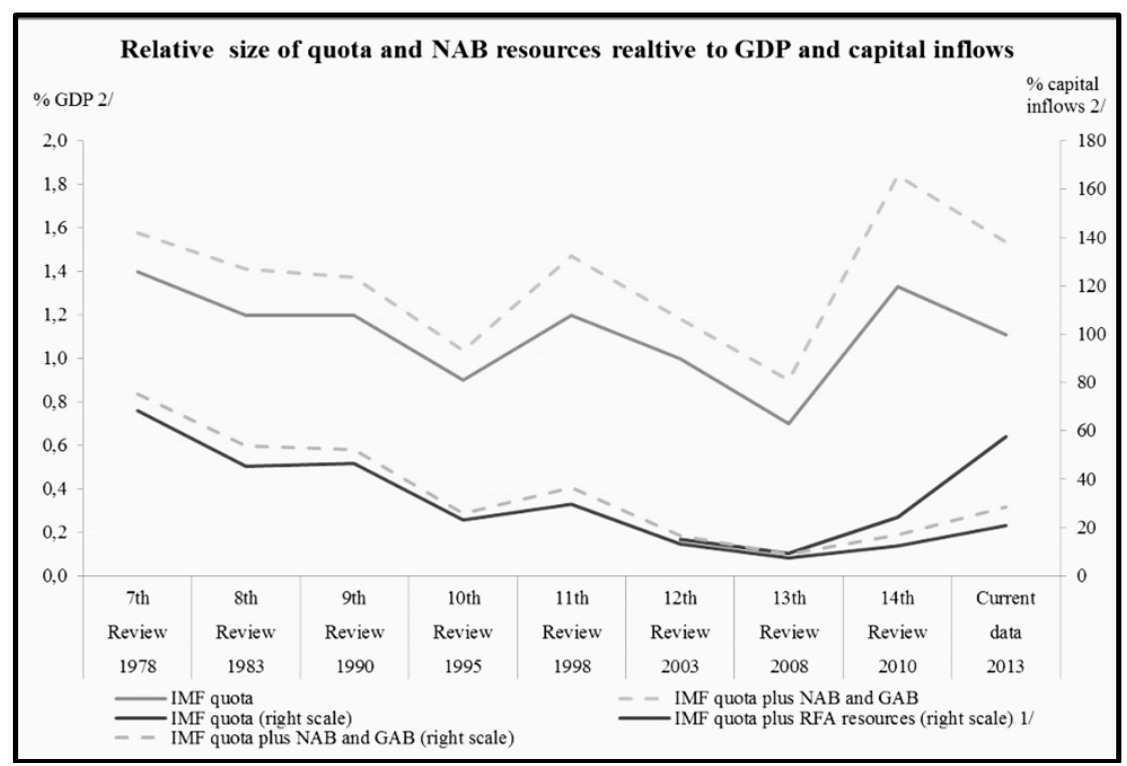

1/ RFAs include resources of CMIM, EFSF, ESM, BRICS fund, AMF and FLAR.

2/ GDP and capital inflows are defined as years average, in the same way as in IMF document (2010): "Fourteenth General Review Quotas - The size of the Fund:Initial Considerations and The Chairman's Concluding Remarks". For example, 14th Review data : ranging from 2004 to 2008 and Current data: ranging from 2009 to 2012. Capital inflows are defined as the sum of inflows of direct, portfolio and other investment.

Source: Based on IMF data (WEO for GDP and IFS for capital inflows), on Annual Reports for IMF, AMF and FLAR, and on CMIM, EFSF, ESM and BRICS fund data.

What it is important is to ensure better coordination between the Fund and RFAs -IMF-EU coordination in European country programs is setting the precedent-, or even central bank swap lines. Here, the Fund tried unsuccessfully some institutionalized options, such as the Board centered Global Stabilization Mechanism and the Multicounty Swap Lines under the general principle that liquidity facilities should be based on the principle of "constructive ambiguity", specially swap lines (IMF 2010 c,d). There is room to recover such debates in order to ensure more certainty, including through better coordination, and building on the liquidity window of the PLL.

${ }^{41}$ For a detailed analysis of RFAs see Garrido, Moreno, and Serra (2013). 


\section{Figure 3b}

Relative size of the Fund's resources

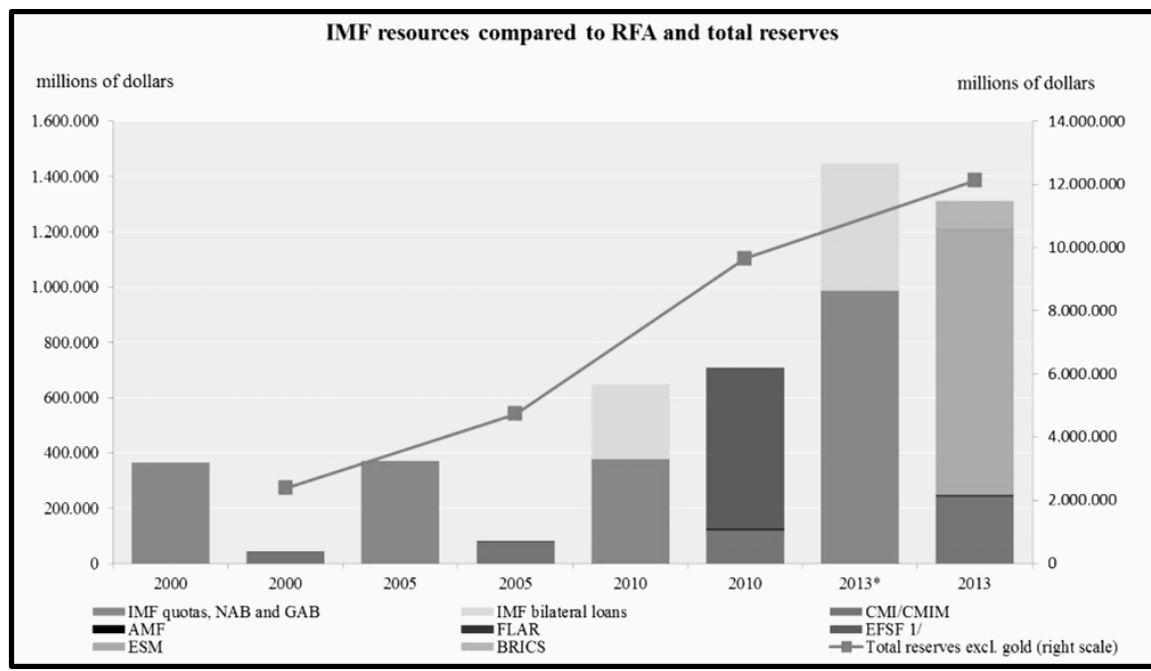

1/ No longer effective for lending under new programs since July 2013.

* Assuming 2010 quota refrom as ratified.

Source: Data based on Annual Reports for IMF, AMF and FLAR, also on CMIM, EFSF, ESM and Reserve Fund of BRICS data. Total reserves excluding gold based on IMF Database (IFS). Glossary: RFA (Regional Financing Arrangements), CMIM (Chiang Mai Initiative Multilateralisation), AMF (Arab Monetary Fund), FLAR (Fondo Latinoamericano de Reservas), EFSF (European Financial Stability Facility), and ESM (European Stabilization Mechanism).

Second, bilateral loans (and Note Purchase Agreements, NPA) have provided added flexibility to Fund's resources ${ }^{42}$. Contrary to quotas or the NAB, they only require a simple majority at the Board and agreement with the country. They have actually been the main support to Fund finances between 2009 and 2011, until the activation on the enlarged NAB in March 2011 ${ }^{43}$. Currently there is a buffer of temporary bilateral loans of up to US\$ 461 billion (almost 50 percent of quota plus NAB resources), and they can be activated again if necessary.

${ }^{42}$ The NPAs are only issued to the official sector. They were established in 2009 as alternative to bilateral loans, to satisfy the preference of the emerging economies to treat their contributions to the IMF as investments within their reserve management strategy.

${ }^{43}$ Particularly the loans by Japan -with a very early contribution of US\$ 100 billion in January 2009-, and the EU. Bilateral loans have their precedent on the in the ad hoc funding sources established in the 60s (the General Agreement to Borrow, GAB), and the trust funds and loan agreements of the 70s to finance the Fund's concessional support through bilateral contributions, which later evolved into today's' Poverty Reduction and Growth Trust, PRGT (see Moreno 2013, chapter 2). 
Additionally, the Fund could consider other alternatives to add even more flexibility to its resources. Particularly interesting would be to add the options of indebtedness with the private sector -as used by development banks, and permitted in the Articles of Agreement of the IMF-, and the leverage of loans ${ }^{44}$. This second alternative would be particularly justifiable in the case of the FCL, given the large resources it detracts from the GRA and particularly, the expectation -by design- that the line will not be used. These options however meet considerable resistance in the Board, mainly under the argument of avoiding dependence on the markets.

\section{CONCLUSIONS}

This year 2014, marks the $70^{\text {th }}$ anniversary of the IMF. As it has done in the past many times -activating Fund lending in the 50s, and strengthening it through the 60s, adapting to the fall of Bretton Woods system in the 70s, and to the sovereign debt crisis and development finance in the 80s, or to capital account crisis in the 90s- the IMF has also adapted its operations and functions to be effective in the aftermath of the global financial crisis.

This time the change has been particularly profound as in the past lustrum there has been a parallel shift in all of the Fund's major policies in governance, surveillance lending, and resources; representing an institutional metamorphosis. In general, these reforms have been introduced gradually, in the sense that much of them had already been under discussion since the late 90s. There is no rabbit out of the hat solutions, but the crisis has served as the catalyst to gain the necessary political support to undertake them.

This paper has tried to summarize the key reforms that have been undertaken and focus on what more can be done, taking into account the current state of the debate within the Fund. On governance, the IMF has broken historical patterns of country representation de facto bringing EMDCs to the decision making their growing power of influence is already a reality, with clear influence on policies such as the design of precautionary facilities or the new capital flow management policy-; albeit it still has to be formalized with the implementation of the 2010 quota reform (pending because of a long-overdue US Congress ratification). In time, successive quota Reviews can gradually continue reducing remaining country underrepresentation. The IMF has also changed its institutional culture moving away from the Washington Consensus. The challenge is to define a new one that will be less of a transnational policy paradigm, and more of a policy oriented framework without monochromatic recommendations and with margin for country-specific policies.

${ }^{44}$ The Fund does not leverage its loans. There is a 1 to 1 ratio between the resources committed under a program and those set aside from the GRA, hence reducing lending capacity on the same amount even if the loan is not disbursed. 
On surveillance, the Fund has quickly moved from a traditional balance of payments and country-based surveillance into an integrated approach adapting it to the reality of a highly interconnected global economy. There is now a greater look at the multilateral-bilateral and macro-financial links, and a strengthened analysis of the financial sector, spillovers, and risks. The challenge is more a question of fine-tuning, with the main next step being bringing a more in depth analysis of structural reforms and the social dimension of the policy advice into the equation. This requires time to acquire expertise, but also developing interinstitutional cooperation where the expertise already lays (OECD, World Bank, ILO).

On lending, crisis resolution facilities (SBA, EFF) have being updated to times of capital account and financial crisis, with much larger access and a more realist conditionality -streamlined and based overall program progress-. The Fund has also added a much-needed insurance function through precautionary lines (FCL, PLL), that protects well-performing countries from exogenous shocks in a context of highly volatile capital flows. The challenge is to anchor this new framework (avoiding going back to moral-hazardism), with a window to revive a light SDRM-type mechanism for sovereign-debt restructuring. Finally on resources, there is room for strengthening coordination with GFSN and to foster PSI in a context where the Fund is no longer the lone-rider of international rescue -and considering that it has already reached the US\$ 1 trillion psychological benchmark in quota and NAB resources-.

All in all, the reforms undertaken in (as) the aftermath of the crisis have gone a long way giving the Fund what it needs to be effective in fulfilling its mission to help ensure the stability of the international economic system.

\section{REFERENCES}

ACEMOGLU, D.; and ROBINSON, J.A. (2012). Why Nations Fail: The Origins of Power, Prosperity and Poverty. New York: Crown. First edition.

BABB, S. (2012). "The Washington Consensus as transnational policy paradigm: Its origins, trajectory and likely successor" in Review of International Political Economy, Vol. 20, No. 2, pp. 268-297.

BAYOUMI, T.; DELL'ARICCIA, G.; HABERMEIER, K.; MANCINI-GRIFFOLI, T. and VALENCIA F. (2014): Monetary Policy in the New Normal. IMF Staff Discussion Note. April.

BLANCHARD, O. (2013): Rethinking Macroeconomic Policy. IMF Direct. April 29, 2013.

BLANCHARD, O. and LEIGH, D. (2013): Growth Forecast Errors and Fiscal Multipliers. IMF Working Paper/13/1.

BLANCHARD, O.; DELL'ARICCIA, G. AND MAURO, P. (2013): Rethinking Macro Policy II: Getting Granular. IMF Staff Discussion Note, April. 
BOUGHTON, J.M. (2011). "The Flight of the Dodo: Is there a Future For the SDR?". ICRIER Conference, Delhi, September 13, 2011.

BOUGHTON, J.M. (2004): The IMF and the Force of History: Ten Events and Ten Ideas That Have Shaped the Institution. IMF working paper. WP/04/75. May, 2004.

BROOKE, M.; MENDES, R.; PIENKOWSKI, A. and SANTOR, E. (2013): Sovereign default and state-contingent debt. Financial Stability Paper $n^{\circ} 27$. Bank of England.

BROOME, A. (2014). Intervention in "Seminar on IMF Surveillance in Europe". Banco de España, February 14, 2014

BUCHHEIT, L.C.; GELPERN, A; GULATI, M.; PANIZZA, U.; WEDER DI MAURO, B. and ZETTELMEYER, J. (2013): Revisiting Sovereign Bankruptcy. Brookings Institution.

CAMDESSUS, M.; LAMFALUSSY, A. and PADOA-SCHIOPPA, T. (2011). Reform of the International Monetary System. Palais-Royal Initiative, February 8, 2011.

CERÓN, J. (2012): La respuesta de la política fiscal a la actividad económica en los países desarrollados", Estudios de Economía Aplicada, 30 (1), pp.1-32.

G20 (2014): Communiqué. Meeting of the G20 Finance Ministers and Central Bank Governors. Washington DC, April 11, 2014.

G20 (2010): The Seoul Summit Document. November 12, 2010.

GARRIDO, I., P. MORENO and X. SERRA (2012): EI IMF y los acuerdos regionales de financiación. Banco de España. 53 Economic Bulletin. March.

GITLIN, R. and HOUSE, B. (2014): A blueprint for a sovereign debt forum. CIGI Papers. No.27, March 2014.

GOLA, C. and SPADAFORA, F. (2009): Financial Sector Surveillance and the IMF. IMF Working paper, WP/09/247. November, 2009.

HALL, R. (1993). "Policy paradigms, social learning, and the State: the case of economic policymaking in Britain" in Comparative Politics, Vol. 25, No. 3 (Apr. 1993), pp. 275296.

IEO of IMF (2003): IMF and Recent Capital Account Crises: Indonesia, South Korea, Brazil. IEO Evaluation Report. July 28, 2003.

IEO of IMF (2011): Evaluation of IMF Performance in the Run-Up to the Financial and Economic Crisis-Multilateral Surveillance. IEO Evaluation Report. January 10, 2011.

IEO of IMF (2013): The Role of the IMF as Trusted Advisor. IEO Evaluation Report.

IMF (2000): Report to the IMF Executive Board of the Quota Formula Review Group. IMF Experts report. April 28.

IMF (2005): Review of the Fund's Transparency Policy. May 24.

IMF (2006): Quotas-Further Thoughts on a New Quota Formula, and Statistical Appendices I and II. November 22, 2006.

IMF (2007): Staff Report on the Multilateral Consultation on Global Imbalances with China, the Euro Area, Japan, Saudi Arabia, and the United States. June 29, 2007

IMF (2008): Reform of Quota and Voice in the International Monetary Fund. Draft Report of the Executive Board to the Board of Governors. March 28, 2008.

IMF (2010a): Central Banking Lessons from the Crisis. May 27, 2010.

IMF (2010b): Review of the Fund's Mandate - Follow-Up on Modernizing Surveillance. July 30, 2010.

IMF (2010c): The Fund's Mandate - Future Financing Role. March 25, 2010. 
IMF (2010d): The Fund's Mandate - The Future Financing Role: Reform Proposals. June 29, 2010.

IMF (2011a): Triennial Surveillance Review - Overview Paper. August 29, 2011.

IMF (2011b). Articles of agreement of the International Monetary Fund (1944).

Washington, D.C. International Monetary Fund, 2011.

IMF (2012a): 2011 Review of Conditionality. Overview Paper. June 19, 2012.

IMF (2012b): Managing Director's Global Policy Agenda. IMFC. October 2012.

IMF (2012c). The IMF's Financial Surveillance Strategy. August 28, 2012.

IMF (2012d): The Liberalization and Management of Capital Flows: An Institutional View. November 14, 2012.

IMF (2012e): Quota Formula Review - Initial Considerations. February 10, 2012.

IMF (2012f): Modernizing the Legal Framework for Surveillance- An Integrated Surveillance Decision. Revised Proposed Decisions. July 17, 2012.

IMF (2012g): Eighth Review of the Fund's Data Standards Initiatives. January 31, 2012.

IMF (2013a): The Managing Director's Global Policy Agenda. October, 2013.

IMF (2013b): Quota Formula - Data Update and Further Considerations - Statistical Appendix. June 7, 2013.

IMF (2013c): IMF Members' Quotas and Voting Power, and IMF Board of Governors.

IMF (2013d): 2014 Triennial Surveillance Review: Concept Note. October 8, 2013.

IMF (2013e): Sovereign debt restructuring - recent developments and implications for the Fund's legal and policy frameworks. April 26, 2013.

IMF (2014a): Fiscal Monitor. Public Expenditure Reform. Making Difficult Choices. April, 2014.

IMF (2014b): The Fund's Liquidity Positions - Review and Outlook, April 7, 2014.

IMF (2014b): Review of Flexible Credit Line, the Precautionary and Liquidity Line, and the Rapid Financing Instrument, January 27.

IIF (2012): Principles for Stable Capital Flows and Fair Debt Restructuring \& Addendum. Report of the Joint Committee on Strengthening the Framework for Sovereign Debt Crisis Prevention and Resolution. Institute of International Finance, IIF Report. Washington, DC. October.

IRC-TF on IMF Issues (2012). "IMF Surveillance following the Triennial Surveillance Review". (mimeo)

IRC-TF on IMF Issues (2014). "IMF Surveillance in Europe". (mimeo)

KRUEGER, A.O. (2002): A New Approach to Sovereign Debt Restructuring. IMF.

KRUGER, M.; LAVINGE, R. and MCKAY, J. (2014): The Role of the IMF on the PostCrisis World. Working Paper (mimeo). Bank of Canada.

LEIPOLD, A. (2014). Intervention in "Seminar on IMF Surveillance in Europe". Banco de España, February 14, 2014

L'HOTELLERIE-FALLOIS, P. and MORENO, P. (2014): Does the International Monetary Fund have sufficient financial resources? Banco de España. 53 Economic Bulletin. January 2014.

LIN, J.Y. (2012): New Structural Economics. A Framework for Rethinking Development and Policy. The World Bank. Washington DC, 20433. 
MARTINEZ-DIAZ, L. (2008): Executive Boards in International Organizations: Lessons for Strengthening IMF Governance. IEO of IMF, series Number: BP/08/08.

MOMANI, B. (2008). "Getting a Seat at the IMF Executive Board Table". Paper presented to the ISA Annual Conference, San Francisco, March 2008.

MOMANI, B. AND LANZ, D. (2014): Shifting IMF Policies since the Arab Uprisings. Policy Brief No. 34. CIGI. March 6, 2014.

MORENO, P. (2012). "Un FMI renovado para una mejor gobernanza global" en Política Exterior. Vol. 26, No149, pp.152-160. Septiembre/octubre.

MORENO, P. (2013): The Metamorphosis of the IMF (2009-2011). Estudios Económicos, No. 78. Banco de España.

MOSCHELLA, M. (2010), Governing Risk: The IMF and Global Financial Crisis. London: Palgrave Macmillan.

MOSCHELLA, M. (2011), "Lagged Learning and the Response to Equilibrium Shock: The Global Financial Crisis and IMF Surveillance", in Journal of Public Policy, Vol. 31, Issue 02, August 2011, pp 121-141.

NOGUEIRA-BATISTA, P.N. (2013). "Reconsidering Macroeconomic Theory, Financial Structures and the Role of Central Banks", in 2013 Money and Banking Conference. The present state of the debate regarding national and international financial restructuring. Banco Central de la República Argentina. Friday, November 15 ${ }^{\text {th }}, 2013$.

OSTRY, D; BERG, A.; TSANGARIADES, C.G. (2014): Redistribution, Inequality, and Growth, IMF staff discussion note, February 2014.

PAULUS, C.G. (2010), "A Standing Arbitral Tribunal as a Procedural Solution for Sovereign Debt Restructuring". In Braga, C. and Vincelette, G.: Sovereign Debt and the Financial Crisis: Will This Time Be Different? (pp.317-329). World Bank Publishers.

PISANI-FERRY, J., SAPIR, A., and WOLFF, G.B., (2011): An evaluation of IMF surveillance of the euro area. Bruegel Blueprint Series. October, 2011.

SKY NEWS (2009): PM: G20 Pledge \$1 Trillion For Economy. Sky News, April 2, 2009.

THE ECONOMIST (2014): America and the IMF. Dereliction of Duty. March $29^{\text {th }}, 2014$.

TRUMAN, E.M. (2014): IMF Reform Is Waiting on the United States. Policy Brief in International Economics 14-9. Peterson Institute for International Economics.

UNITED NATIONS (2009): Report of the Commission of Experts of the President of the United Nations General Assembly on Reforms of the International Monetary and Financial System. September 21, 2009.

VASISHTHA, G. AND LAVIGNE, R. (2010). "Assessing the Implementation of the IMF's 2007 Surveillance Decision", in Review of International Organizations, Volume 5, Issue 1, pp. 27-52.

VIÑALS, J., PAZARBASIOGLU, C., SURTI, J., NARAIN, A., ERBENOVA, M., AND CHOW A.(2013): Creating a Safer Financial System: Will the Volcker, Vickers, and Liikanen Structural Measures Help? . IMF Staff Discussion Note 13/4. April.

WILLIAMSON, J. (1990). Latin American Adjustment: How Much Has Happened? Washington: Institute for International Economics. 